\title{
Numerical and Chemical Classification of Nocardia amarae
}

\author{
By M. GOODFELLOW ${ }^{1 *}$ D. E. MINNIKIN, ${ }^{2}$ C. TODD, ${ }^{1}$ \\ G. ALDERSON, ${ }^{+}$S. M. MINNIKIN ${ }^{2}$ AND M. D. COLLINS ${ }^{1} \ddagger$ \\ ${ }^{1}$ Department of Microbiology, The University, Newcastle upon Tyne NE1 7RU, U.K. \\ ${ }^{2}$ Department of Organic Chemistry, The University, Newcastle upon Tyne NE1 7RU, U.K.
}

(Received 1 May 1981; revised 17 July 1981)

Twenty-one strains of Nocardia amarae and marker cultures of Mycobacterium, Nocardia, $R$ hodococcus and the 'aurantiaca' taxon were subjected to numerical phenetic analyses using 92 unit characters. The data were examined using the simple matching $\left(S_{S M}\right)$, Jaccard $\left(S_{J}\right)$ and pattern $\left(D_{p}\right)$ coefficients and clustering was achieved using the unweighted average linkage algorithm. Neither cluster nor aggregate cluster composition was markedly affected by the coefficient used or by test error, estimated at $1.5 \%$. The $N$. amarae strains formed a distinct and homogeneous cluster which showed its highest similarity to phena equated with Nocardia asteroides, Nocardia brasiliensis and Nocardia otitidis-caviarum. The nonhydroxylated fatty acid composition and overall size of the mycolic acids was similar to that found to be characteristic of Nocardia sensu stricto, though the long-chain in the 2-position of the mycolic acids was relatively much richer in monounsaturated components. Nocardia amarae, in containing dihydrogenated menaquinones with nine isoprene units, is clearly distinguished from established representatives of Nocardia.

\section{INTRODUCTION}

Nocardia amarae was proposed by Lechevalier \& Lechevalier (1974) for novel actinomycetes isolated in large numbers from foam formed on the surface of aeration tanks in activated-sludge sewage-treatment plants. The organism contained meso-diaminopimelic acid, arabinose and galactose (wall chemotype IV sensu Lechevalier \& Lechevalier, 1970), mycolic acids with characteristic unsaturated branches in the 2-position and was considered to be related to Nocardia ('Mycobacterium') rhodochrous on the basis of chemical and physiological criteria. The genus Rhodococcus was subsequently resurrected for strains labelled ' $M$ '. rhodochrous (Tsukamura, 1974; Goodfellow \& Alderson, 1977).

In the absence of extensive systematic studies little is known of the detailed relationships of $N$. amarae and other wall chemotype IV, mycolic acid-containing strains classified in the genera Corynebacterium sensu stricto, Mycobacterium, Nocardia, Rhodococcus and the 'aurantiaca' taxon (Goodfellow \& Minnikin, 1977, 1981; Goodfellow et al., 1978; Minnikin et al., 1978; Minnikin \& Goodfellow, 1980, 1981). Nocardia amarae strains do, however, contain fatty acids and polar lipids similar to those of Nocardia and Rhodococcus (Lechevalier et al., 1977), have a DNA base composition within the range 60 to $66 \mathrm{~mol} \%$ guanine plus cytosine, and with one exception form a distinct DNA homology group (Mordarski et al., 1977; Goodfellow \& Minnikin, 1981). Further, in preliminary DNA :rRNA pairing experiments the type strain of $N$. amarae was more closely related to Nocardia strains than to reference cultures of Mycobacterium and Rhodococcus (Mordarski

\footnotetext{
† Present address: School of Studies in Medical Sciences, University of Bradford, Bradford BD7 IDP, U.K.
}

¥ Present address: National Institute for Research in Dairying, Shinfield, Reading RG2 9AT, U.K. 
Table 1. Designation and source of strains assigned to subcluster $3 A$ and cluster 5 in the $S_{S M} / U P G M A$ analysis

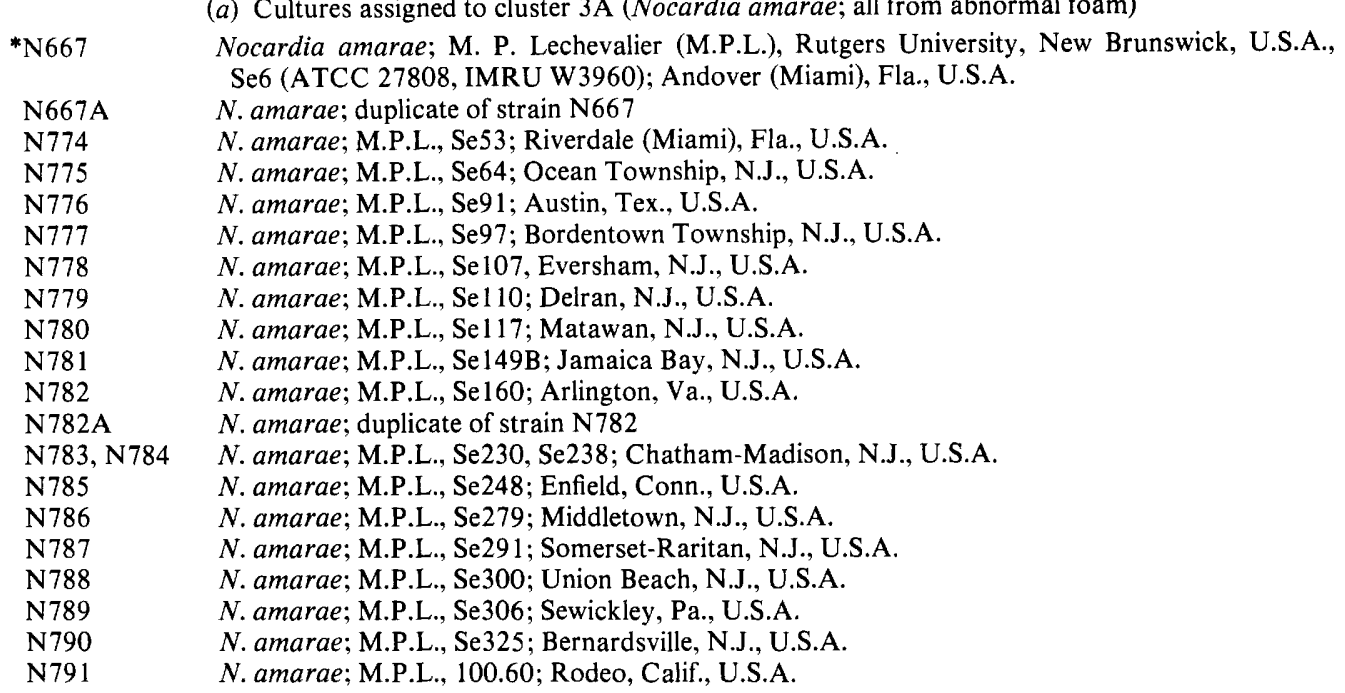

(b) Cultures assigned to cluster 5A (Corynebacterium diphtheriae)

*C67 Corynebacterium diphtheriae var. minimus; NCTC 10681

C14 C. diphtheriae var. intermedius; NCTC 3987

${ }^{*} \mathrm{C} 12 \quad$ Corynebacterium bovis; NCTC 3224

C103 C. bovis; J. E. Shreeve, Central Veterinary Laboratory, Weybridge, U.K., 120B

Corynebacterium pseudotuberculosis; H. R. Carne, Pathology Department, Cambridge University, U.K., OV $137 \mathrm{c}$

C146 C. pseudotuberculosis; H. R. Carne, OV $137 \mathrm{~d}$

C150 C. pseudotuberculosis; H. R. Carne, OV 1134

C152 C. pseudotuberculosis; H. R. Carne, Cap 16

$\mathrm{C} 19$

(e) Single member cluster

Corynebacterium pseudodiphtheriticum; NCTC 231

* Type strain.

et al., 1980). However, some strains of $N$. amarae have been reported to lack the galactose characteristic of Nocardia sensu stricto (Gordon et al., 1978), while the type strain was not lysed by nocardiophages (Williams et al., 1980) and was only loosely associated with true nocardiae in numerical phenetic analyses (Orchard et al., 1977; Orchard \& Goodfellow, 1980; Goodfellow \& Pirouz, 1982).

In the present study representatives of $N$. amarae and marker cultures of Corynebacterium sensu stricto, Mycobacterium, Nocardia, Rhodococcus and the 'aurantiaca' taxon were compared using numerical phenetic techniques. The fatty acid, mycolic acid and isoprenoid quinone composition of the $N$. amarae strains was also determined.

\section{METHODS}

Strains, and collection and coding of data. Twenty-one $N$. amarae strains, 9 corynebacteria, 10 rapidly growing mycobacteria, 13 nocardiae, 62 rhodococci and 8 aurantiaca strains were studied. Only histories of the Corynebacterium and $N$. amarae strains are given (Table 1) as those of the other test organisms have already been 
cited (Goodfellow et al., 1978). All of the cultures were maintained on glucose yeast extract agar (Gordon \& Mihm, 1962) at room temperature.

The corynebacteria and $N$. amarae strains were examined for 92 unit characters using tests described elsewhere (Goodfellow, 1971; Lacey \& Goodfellow, 1975; Goodfellow \& Alderson, 1977), and the results were added to the data bank existing on the other organisms (Goodfellow et al., 1978).

Computer analysis. Data were analysed using the Clustan 1A program (Wishart, 1968) on an IBM 370/180 computer, using the simple matching coefficient $\left(S_{S M}\right.$; Sokal \& Michener, 1958), which includes both positive and negative matches, the Jaccard coefficient $\left(S_{J} ;\right.$ Sneath, 1957), which includes positive matches only, and the pattern coefficient $\left(D_{p}\right.$; Sneath, 1968), which seeks to allow for differences in growth rates, incubation periods and similar factors which might contribute to overall dissimilarity between strains. Data were sorted using the unweighted average linkage (UPGMA) algorithm (Sneath \& Sokal, 1973); those from the $S_{S M} /$ UPGMA analysis are presented as an abbreviated dendrogram (Fig. 1).

Lipid analyses. The $N$. amarae strains were grown in shake culture at $30^{\circ} \mathrm{C}$ for up to $7 \mathrm{~d}$ in modified Sauton's medium (Mordarska et al., 1972), checked for purity at maximum growth, killed by shaking overnight with formalin $(1 \%, v / v)$, separated by centrifugation, washed with distilled water, and freeze-dried.

Freeze-dried bacteria $(50 \mathrm{mg})$ were degraded by acid methanolysis, and hexane extracts were examined for long-chain components by single-dimensional thin-layer chromatography (t.l.c.), as described previously (Minnikin et al., 1975), using Merck silica gel $\mathrm{H}(0.5 \mathrm{~mm}$ layers) and a developing mixture of petroleum ether (b.p. $\left.60-80^{\circ} \mathrm{C}\right) /$ diethyl ether $(85: 15, \mathrm{v} / \mathrm{v})$. Two-dimensional t.l.c. of methanolysates was performed using $10 \times 10 \mathrm{~cm}$ plates cut from silica gel $60 \mathrm{~F}_{254}$ aluminium sheets (Merck no. 5554) and a triple development with petroleum ether (b.p. $\left.60-80^{\circ} \mathrm{C}\right) /$ acetone $(95: 5, \mathrm{v} / \mathrm{v})$ in the first direction, followed, in the second direction, by a single development with toluene/acetone $(97: 3, \mathrm{v} / \mathrm{v})$ (Minnikin et al., 1980).

Long-chain components were isolated by preparative t.l.c. on layers $(1 \mathrm{~mm})$ of Merck silica gel $\mathrm{PF}_{254}+366$, separated bands being detected with ultraviolet light $(366 \mathrm{~nm})$. Long-chain fatty acid methyl esters were analysed by isothermal gas chromatography on a Perkin-Elmer F11 flame-ionization instrument using nitrogen as carrier gas and stainless steel columns $(0 \cdot 125$ in, o.d.) packed with $10 \%$ Silar 10C on 100-120 mesh Gas-Chrom Q (6 m long; Applied Science Laboratories) at $210^{\circ} \mathrm{C}$ or $2.5 \%$ OV-1 on 80-100 mesh Chromosorb G AW-DMCS ( $2 \mathrm{~m}$ long; Phase Separations) at $180^{\circ} \mathrm{C}$. Analyses using these polar and non-polar columns allowed the positive identification of the major long-chain fatty acid methyl esters from $N$. amarae, but for the quantification of minor amounts of methyl esters having exceptionally long chains a shorter $(1 \mathrm{~m}) \mathrm{OV}-1$ column was used, with a programmed temperature increase at $6^{\circ} \mathrm{C} \mathrm{min}-1$ from 120 to $300^{\circ} \mathrm{C}$.

Mycolic acid methyl esters were examined by pyrolysis gas chromatography using the $6 \mathrm{~m}$ Silar $10 \mathrm{C}$ and $2 \mathrm{~m}$ OV-1 columns, and by mass spectrometry on an AEI MS9 instrument with a direct insertion probe, an ionizing voltage of $70 \mathrm{eV}$ and a temperature range of 190 to $220^{\circ} \mathrm{C}$. The solubility of mycolic acids of N. amarae $\mathrm{N} 780$ in ethanol/diethyl ether $(2: 1, \mathrm{v} / \mathrm{v})$ was assessed by the method of Hecht \& Causey (1976).

Isoprenoid quinones were extracted, purified and analysed by mass spectrometry as described by Collins et al. (1977).

\section{RES ULTS}

Clustering of strains using the $S_{S M}, S_{J}$ and $D_{P}$ coefficients and the UPGMA algorithm

The corynebacteria, mycobacteria, nocardiae, rhodococci and aurantiaca strains were recovered in five aggregate clusters defined at or just below the $70 \%$ similarity level in the $S_{S M}$ /UPGMA analysis (Fig. 1). Both aggregate clusters and subclusters were named, where possible, after the type or authentic strains they contained (Table 1); the codes for the aggregate clusters are the same as those used in other numerical phenetic surveys (Goodfellow \& Alderson, 1977; Goodfellow et al., 1978; Goodfellow et al., 1982). The composition of the Mycobacterium, Rhodococcus and 'aurantiaca' aggregate clusters were as in previous analyses (Goodfellow et al., 1978, 1982) and will not be considered here.

The $N$. amarae strains formed a distinct homogeneous cluster lying on the periphery of the Nocardia aggregate cluster but separate from phena corresponding to Corynebacterium sensu stricto, Mycobacterium, Rhodococcus and the 'aurantiaca' taxon (Fig. 1). The corynebacteria formed the most diffuse aggregate cluster containing three clusters $-5 \mathrm{~A}, 5 \mathrm{~B}$ and $5 \mathrm{C}$ - corresponding to $C$. diphtheriae, C. bovis and C. pseudotuberculosis, respectively (Table 1).

Essentially similar results were obtained in both the $S_{J} /$ UPGMA and $D_{P} /$ UPGMA analyses, although in the latter the $N$. amarae strains fell outside the aggregate Nocardia cluster and the $C$. bovis and $C$. diphtheriae clusters were recovered as a single phenon. 


Cluster
strains

Fig. 1. A simplified dendrogram showing the relationships between aggregate clusters and subclusters based on the $S_{S M}$ coefficient and the average linkage algorithm (UPGMA).

\section{Reproducibility of results}

The inclusion of two duplicate cultures of $N$. amarae (Table 1) in the analysis enabled experimental test error to be estimated. The probability $(p)$ of an erroneous result averaged $1.5 \%$, equal to an observed $S_{S M}$ value of about $97 \%$ between duplicate strains.

\section{Differentiation of Nocardia amarae, $N$. asteroides, $N$. brasiliensis and N. otitidis-caviarum}

The percentage of positive responses to each test for the $N$. amarae strains is compared in Table 2 with data obtained in corresponding studies on $N$. asteroides, $N$. brasiliensis and $N$. otitidis-caviarum (Goodfellow, 1971; Lacey \& Goodfellow, 1975). The 15 tests with the greatest resolving power for the differentiation of the four species are given in Table 3 . It is evident from Table 2 that $N$. asteroides is heterogeneous, a fact that was underlined in a recent numerical phenetic survey (Orchard \& Goodfellow, 1980).

\section{Lipid analyses}

Whole-organism acid methanolysates from all the $N$. amarae strains gave similar patterns on single- and two-dimensional t.l.c.; an example of the latter is given in Fig. 2 for the type strain N667. The principal long-chain components in $N$. amarae corresponded to non-hydroxylated fatty acids and mycolic acid methyl esters (Minnikin et al., 1980) but 
minor amounts of other components were detected in most strains (Fig. 2). These minor long-chain compounds were not characterized, but the least polar components (Fig. 2) were possibly nocardols - long-chain alcohols closely related to mycolic acids (Minnikin et al., 1980). The non-hydroxylated fatty acid methyl esters were isolated by preparative t.l.c. and the results of gas chromatographic analyses on both polar and non-polar phases are shown in Table 4. The principal non-hydroxylated fatty acids in $N$. amarae were $\mathrm{C}_{16}$ and $\mathrm{C}_{18}$ straight-chain saturated and monounsaturated acids and an acid whose ester cochromatographed with authentic 10-methyloctadecanoate prepared from Mycobacterium avium. Minor amounts of methyl esters having chains longer than 18 carbons were not positively identified (Table 4).

Mycolic acid methyl esters from N. amarae strains were also isolated from methanolysates by preparative t.l.c. and subjected to mass spectrometry and pyrolysis gas chromatography. Methyl esters of mycolic acids having substantial amounts of unsaturated chains in the 2-position fragment on mass spectrometry as shown in Fig. 3 (Goodfellow et al., 1978; Collins et al., 1982). The highest peaks in the mass spectra correspond to anhydromycolates resulting from the elimination of a molecule of water from the parent mycolate. Cleavage according to $a$ and $a^{\prime}$ (Fig. 3) involves net transfer of the hydroxyl hydrogen atom to produce long-chain methyl esters and aldehydes (meroaldehydes). The elements of methanol are readily lost from monounsaturated esters formed by cleavage $a$ to give characteristic fragments X (Fig. 3) (Goodfellow et al., 1978; Collins et al., 1982). The overall sizes of the side-chains $\mathrm{R}_{1}$ (Fig. 3) are also revealed by the presence of fragments Y due to cleavage $b$.

The characteristic mass spectral fragmentation pattern, outlined above, is exemplified by the partial mass spectrum of the methyl mycolates from $N$. amarae N667 shown in Fig. 4. Partial mass spectra of the mycolic esters from the remaining strains of $N$. amarae (Table 1) have been deposited with the British Library Lending Division, Boston Spa, Yorkshire LS23 7BQ, as Supplementary Publication No. SUP 28012 (5 pages). (Copies may be obtained from the BLLD on demand; where possible, requests should be accompanied by prepaid coupons, held by many university and technical libraries and by the British Council.) Peaks corresponding to anhydromycolates (Fig. 3) in the mass spectra of the mycolic acid methyl esters from all representatives of $N$. amarae, with the exception of strain N786, were closely similar to those shown in Fig. 4, and a summary of their distribution is given in Table 5 . The anhydromycolate fragments in the mass spectrum of the mycolic esters from N. amarae N786 were significantly different (Table 6). Peaks corresponding to pyrolytic release of meroaldehydes and long-chain esters (Etémadi, 1967; Figs 3,4) were observable in the mass spectra of all the mycolic esters analysed. The competing pathways (Fig. 3 ) leading to peaks derived from long-chain esters hamper the quantitative estimation of the composition of the long-chains in the 2-position of the mycolic acids (Collins et al., 1982) and the precise composition was therefore established by pyrolysis gas chromatography (Etemadi, 1967); the results are shown in Table 7 . The mycolic acids of $N$. amarae N780 were soluble in ethanol/diethyl ether $(2: 1, \mathrm{v} / \mathrm{v})$ as tested by the procedure of Hecht \& Causey (1976).

Extracts of the $N$. amarae strains contained menaquinones which co-chromatographed on t.l.c. with vitamin $\mathrm{K}$. The most significant peak in the spectra occurred at $m / e 786$ corresponding to a dihydrogenated menaquinone with nine isoprene units, abbreviated as MK-9 $\left(\mathrm{H}_{2}\right)$; smaller peaks at $m / e 650,716,718$ and 784 correspond to the minor components MK-7 $\left(\mathrm{H}_{2}\right)$, MK-8, MK-8 $\left(\mathrm{H}_{2}\right)$ and MK-9 (Table 8).

\section{DISCUSSION}

In the numerical analysis, phenon composition was not markedly affected either by the statistics used or by the $1.5 \%$ test error. In the $S_{S M}, S_{J}$ and $D_{P}$ analyses with UPGMA, the $N$. amarae strains were recovered as a homogeneous cluster which was clearly separated from the phena in aggregate clusters corresponding to Corynebacterium sensu stricto, 
Table 2. A comparison of the characteristics of Nocardia amarae with those of well established species of Nocardia

Results show the percentage frequencies of positive characters.

Character

N. amarae

(19 strains)

N. asteroides*

(42 strains)

N. brasiliensis*

(10 strains)

N. otitidiscaviarum*

Staining and colony morphology:

Strongly acid-fast

Aerial hyphae, sparse

0

90

Aerial hyphae, moderate

Aerial hyphae, abundant

Colonies white, cream, tan

Colonies pink, red, orange

Diffusible exopigment

Elevation convex

Elevation irregular

Margin entire

Margin filamentous

Degradation of:

Casein

Elastin

Hypoxanthine

Tween 40

Tween 60

Tyrosine

Xanthine
Tween 20

46
98
77
62
17
77
43
12
89
0
100

100

\section{0}

0
5

100

97

84

0

0

Growth on sole carbon source (at $1 \mathrm{~g} \mathrm{l}^{-1}$ ):

L-Arabinose

Cellobiose

Ethanol

Fructose

Galactose

Glycerol

Inositol

Inulin

Lactose

Maltose

Mannose

Mannitol

Rhamnose

Salicin

Sorbitol

Sucrose

Trehalose

Xylose

Growth on sole carbon source (at $0.1 \mathrm{~g} \mathrm{l}^{-1}$ ):

Acetamide

p-Cresol

$m$-Hydroxybenzoic acid

p-Hydroxybenzoic acid

Pimelic acid

Sebacic acid

Testosterone

L-Tyrosine

Sodium adipate

Sodium benzoate

Sodium citrate

Sodium fumarate

Sodium gluconate

Sodium malate

Sodium octanoate
100

100

0
0
0

100

90

16

100

85

11

0

95

100

90

90

100

0

95

100

0

(10 strains)

$\begin{array}{rr}100 & 100 \\ 70 & 0 \\ 100 & 90 \\ 0 & 20 \\ 100 & 80 \\ 0 & 0 \\ 100 & 100\end{array}$

100

100

100

20

10

10

100

50

90

60

20

100

90

20

80

100

$$
\begin{array}{r}
0 \\
0 \\
90 \\
90 \\
70 \\
70 \\
0 \\
100
\end{array}
$$

100

80

90

90

100

10

100

100

90

0
30

30
0

70

100

30

$$
\begin{array}{r}
0 \\
30
\end{array}
$$

100

0

10
90

90
0

0 
Table 2-continued

\begin{tabular}{|c|c|c|c|c|}
\hline & N. amarae & N. asteroides* & N. brasiliensis* & $\begin{array}{l}\text { N. otitidis- } \\
\text { caviarum }\end{array}$ \\
\hline Sodium propionate & 100 & 100 & 100 & 80 \\
\hline Sodium succinate & 100 & 100 & 80 & 100 \\
\hline \multicolumn{5}{|c|}{ Growth on sole carbon/nitrogen source: } \\
\hline Acetamide & 53 & 14 & 50 & 0 \\
\hline Serine & 0 & 0 & 70 & 0 \\
\hline \multicolumn{5}{|l|}{ Growth in the presence of: } \\
\hline $0.0001 \%(\mathrm{w} / \mathrm{v})$ Crystal violet & 100 & 38 & 10 & 50 \\
\hline $0.001 \%(\mathrm{w} / \mathrm{v})$ Crystal violet & 100 & 2 & 0 & 10 \\
\hline $0.01 \%(\mathrm{w} / \mathrm{v})$ Phenol & 100 & 86 & 100 & 90 \\
\hline $0.1 \%(\mathrm{w} / \mathrm{v})$ Phenol & 0 & 43 & 30 & 50 \\
\hline $0.2 \%(\mathrm{w} / \mathrm{v})$ Phenyl ethanol & 64 & 43 & 50 & 60 \\
\hline $0.3 \%(\mathrm{w} / \mathrm{v})$ Phenyl ethanol & 0 & 22 & 20 & 40 \\
\hline $0.01 \%(\mathrm{w} / \mathrm{v})$ Sodium azide & 90 & 62 & 30 & 40 \\
\hline $0.02 \%(\mathrm{w} / \mathrm{v})$ Sodium azide & 80 & 12 & 0 & 0 \\
\hline $5 \%(\mathrm{w} / \mathrm{v})$ Sodium chloride & 27 & 84 & 100 & 100 \\
\hline $7 \%(\mathrm{w} / \mathrm{v})$ Sodium chloride & 0 & 36 & 0 & 80 \\
\hline Susceptibility to 10 i.u. penicillin & 100 & 24 & 10 & 30 \\
\hline \multicolumn{5}{|l|}{ Enzyme activity: } \\
\hline Allantoin hydrolysis. weak & 69 & 86 & 100 & 100 \\
\hline Allantoin hydrolysis, strong & 0 & 24 & 70 & 50 \\
\hline Nitrate reduction & 100 & 98 & 100 & 100 \\
\hline$p$-Nitrophenoloxidase & 0 & 14 & 0 & 0 \\
\hline Urea hydrolysis, weak & 100 & 98 & 100 & 100 \\
\hline Urea hydrolysis, strong & 95 & 79 & 100 & 100 \\
\hline \multicolumn{5}{|l|}{ Growth at: } \\
\hline $10^{\circ} \mathrm{C}$ & 16 & 26 & 60 & 30 \\
\hline $40^{\circ} \mathrm{C}$ & 0 & 100 & 90 & 90 \\
\hline $45^{\circ} \mathrm{C}$ & 0 & 64 & 20 & 60 \\
\hline $50^{\circ} \mathrm{C}$ & 0 & 31 & 0 & 10 \\
\hline
\end{tabular}

No strains produced yellow colonies or $m$-nitrophenoloxidase, degraded adenine, used adonitol, melezitose. raffinose (at $1 \mathrm{~g}^{-1}$ ), benzamide, sodium lactate or tartrate (at $0 \cdot 1 \mathrm{~g}^{-1}$ ) as sole carbon source or trimethylenediamine as sole source of carbon and nitrogen, but they all formed a mycelium, contained lipid LCN-A and grew on glucose, sodium acetate, butyrate and pyruvate $\left(\right.$ at $\left.0.1 \mathrm{~g} \mathrm{l}^{-1}\right)$ as sole carbon source.

* Data from Goodfellow (1971) and Lacey \& Goodfellow (1975).

Mycobacterium, Rhodococcus and the 'aurantiaca' taxon. The $N$. amarae strains showed their highest similarity to $N$. asteroides, $N$. brasiliensis and $N$. otitidis-caviarum but fell outside the aggregate Nocardia cluster in the $D_{P}$ analysis. The numerical findings are, therefore, in agreement with previous studies which indicated that a loose association existed between $N$. amarae N667 and Nocardia sensu stricto (Orchard et al., 1977; Orchard \& Goodfellow, 1980; Goodfellow \& Pirouz, 1982). Nocardia amarae can readily be distinguished from established species of Nocardia using biochemical and physiological criteria (Table 3; Lechevalier \& Lechevalier, 1974).

The close similarity between Corynebacterium sensu stricto and Rhodococcus, and between $C$. bovis and $C$. diphtheriae, in the $D_{P}$ analysis is a reflection of the small number of positive responses shown by the corynebacteria. It has already been shown (Goodfellow et al., 1978) that when organisms that produce many positive responses are compared with less vigorous strains then pattern differences will be artificially small.

The lipid data are in good agreement with those from previous studies (Lechevalier \& Lechevalier, 1974; Lechevalier et al., 1976, 1977). Thus, the $N$. amarae strains contain major amounts of straight-chain, saturated and unsaturated acids and tuberculostearic acid and 
Table 3. Characters with the greatest resolving power for differentiating Nocardia amarae, $N$. asteroides, $N$. brasiliensis and $N$. otitidis-caviarum

Results show the percentage frequencies of positive characters.

\section{Character}

N. amarae

Colony morphology;

Colonies white, cream, $\tan$

Colonies pink, red, orange

Degradation of:

Elastin
Hypoxanthine
Tyrosine

Xanthine

Growth on sole carbon source (at $1 \mathrm{~g} \mathrm{l}^{-1}$ ):

Glycerol

Inositol

Rhamnose

Growth on sole carbon source (at $0.1 \mathrm{~g} \mathrm{l}^{-1}$ )

Pimelic acid

Sodium gluconate

Testosterone

Growth in the presence of:

$0.001 \%(w / v)$ Crystal violet

$0.02 \%(\mathrm{w} / \mathrm{v})$ Sodium azide

Growth at $40^{\circ} \mathrm{C}$
$N$. asteroides

N. brasiliensis

$N$. otitidiscaviarum
17
77

77

\section{0}

5

0

0

82

2

36

90

100

100

0

100

80

0

82
0

70

0

90

0

100

10

90

100

0

0

0

0

100

10
90

0

10

0

90

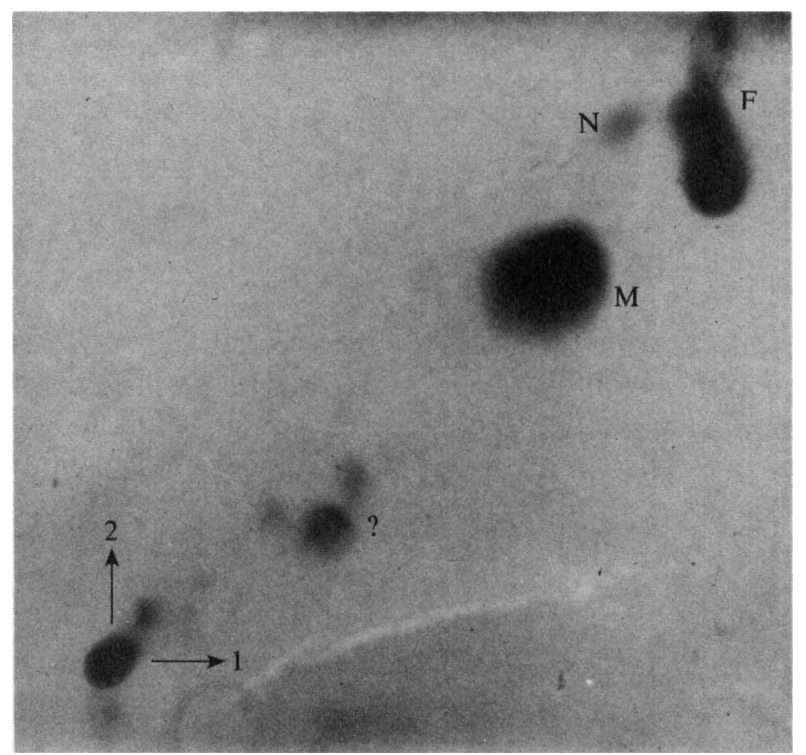

Fig. 2. Two-dimensional t.l.c. of whole-organism acid methanolysate of $N$. amarae N667. A triple development with petroleum ether (b.p. $\left.60-80^{\circ} \mathrm{C}\right) /$ acetone $(95: 5, \mathrm{v} / \mathrm{v})$ in the first direction was followed by a single development with toluene/acetone $(97: 3, \mathrm{v} / \mathrm{v})$ in the second direction. Abbreviations: F, non-hydroxylated fatty acid methyl esters; M, mycolic acid methyl esters; N, possible long-chain alcohol ('nocardol'); ?, unknown components. 
$\bar{i}$

$|\stackrel{n}{o}|$

$\stackrel{2}{-}$

$\stackrel{\infty}{\check{1}}$

$\stackrel{\infty}{\stackrel{\infty}{-}}$

$\stackrel{?}{?}$<smiles>[Mg][Mg]</smiles>

ㄴํㄴ

$\stackrel{-1}{9}$

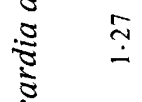

$|\dot{\dot{\theta}}||||| \overrightarrow{\dot{\sim}}|1||||= \pm| \mid 1$

$|\stackrel{2}{-}||||\stackrel{\leftrightarrow}{\dot{m}}|=z=|| z=|| \mid$

$\sum_{0}^{0} \stackrel{?}{-}$

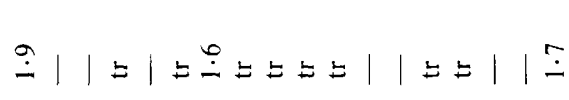

| $|1| 1|1| 1|1| 1|||| \stackrel{\dot{m}}{\mid}$

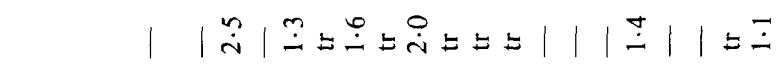

$\stackrel{9}{\dot{2}}$

$|\hat{0}| 1|1 \stackrel{\sim}{=}| 1|1| 1|1|$

$\stackrel{0}{\check{-}}$

$|\tilde{o}||||\dot{\leftrightarrow}|||||||||=$

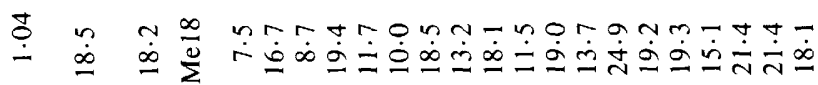

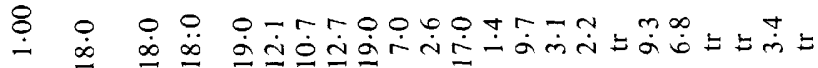

ఏ)

\& 0 o

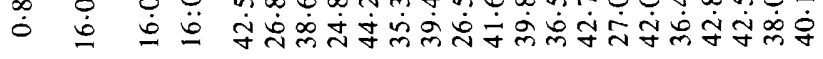

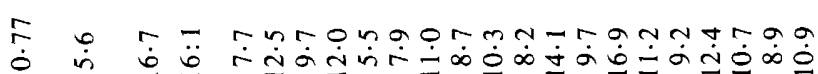

$\frac{\sqrt{0}}{\stackrel{0}{0}}$

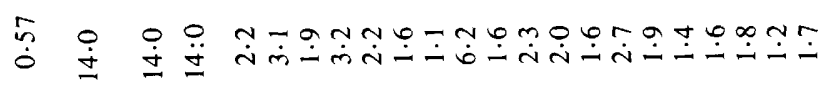

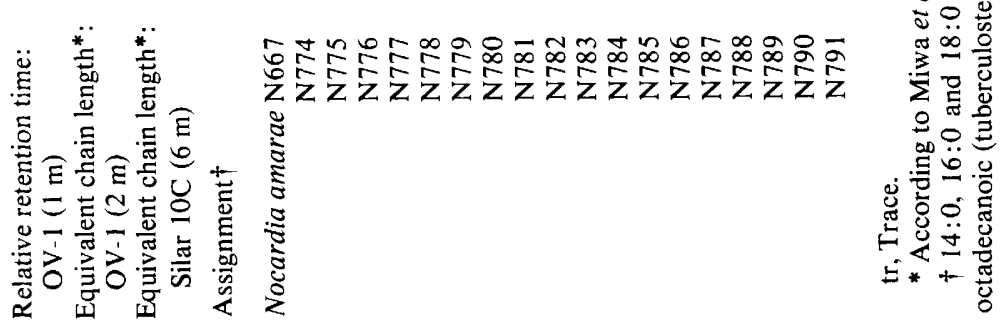




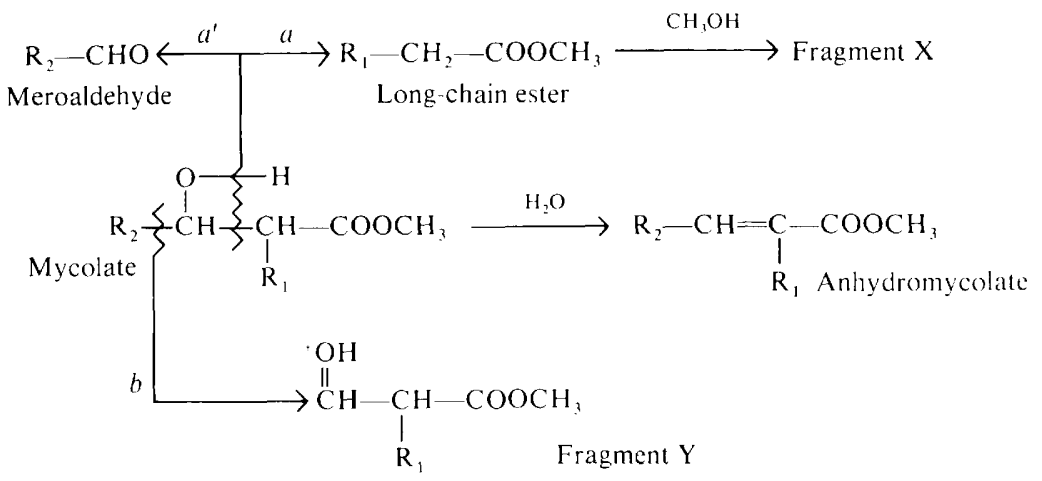

Fig. 3. Mass spectral fragmentation pathways characteristic of mycolic acid methyl esters from strains of $N$. amarae.

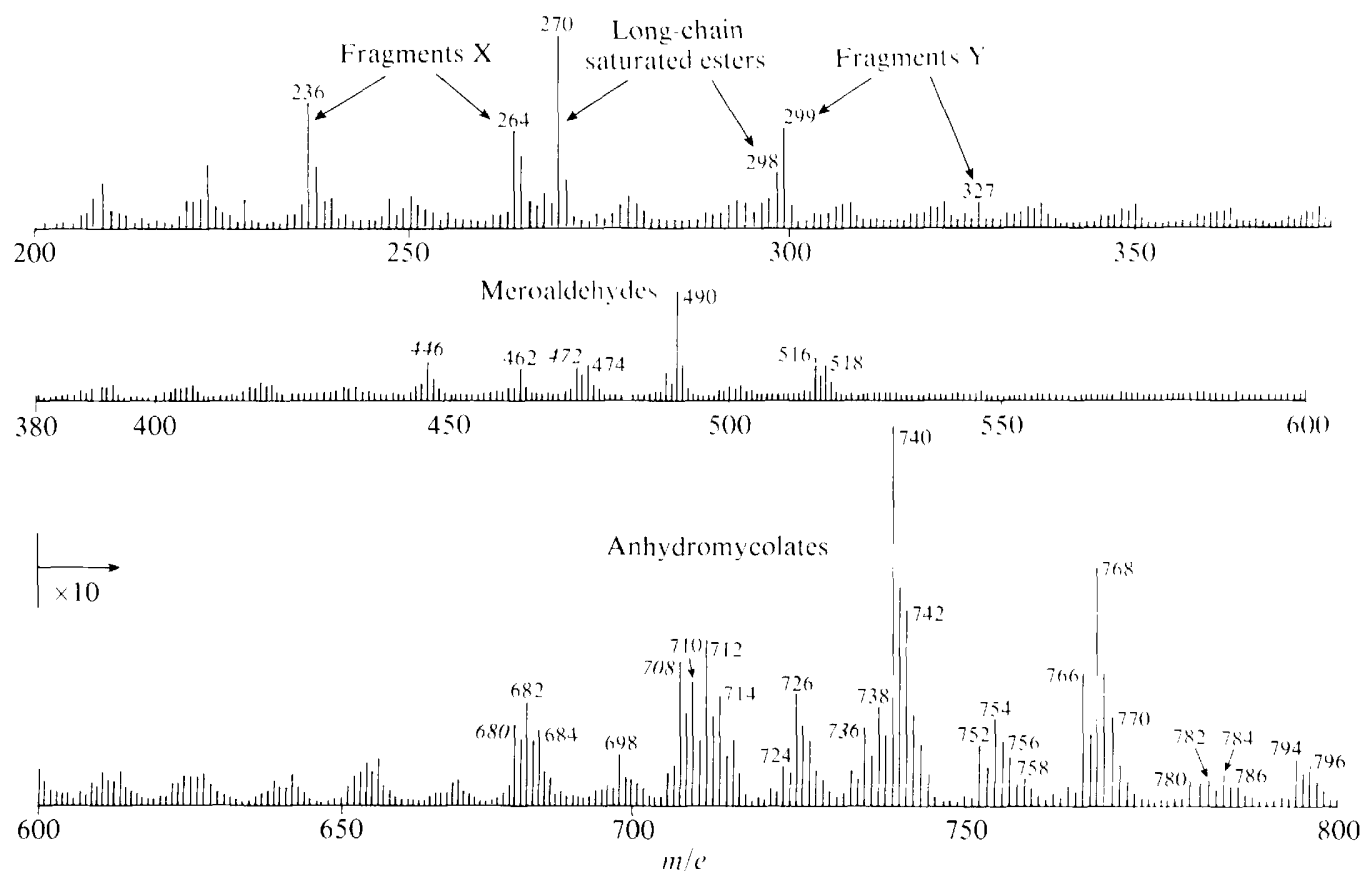

Fig. 4. Partial mass spectrum of the mycolic acid methyl esters from N. amarae N667; the spectrum was directly copied and is therefore not normalized. Peaks numbered in italics in the anhydromycolate region probably correspond to loss of the elements of methanol from the major anhydromycolates and those in the meroaldehyde region are probably dehydration products. The origin of fragments $\mathrm{X}$ and $\mathrm{Y}$ is explained by reference to the text and Fig. 3 .

produce mycolic acids which characteristically have substantial amounts of unsaturated chains in the 2-position. Mass spectral analysis of the mycolic acids from N. amarae strains showed that they were similar in overall size to those of nocardiae since they contained 46 to 54 carbons with up to three double bonds (Minnikin \& Goodfellow, 1980) with $\mathrm{C}_{50}$ and $\mathrm{C}_{52}$ as the major components. However, $N$. amarae strains contain major amounts of dihydrogenated menaquinones with nine isoprene units $\left[\mathrm{MK}-9\left(\mathrm{H}_{2}\right)\right]$ and can thereby be 
$\overline{\bar{Z}}+++\cdot++++++++++++++++++++++$.

$\underset{\mathrm{z}}{\stackrel{8}{\mathrm{Z}}}+++\cdot+++++\cdot+\underset{+}{+}++++++++++++++$.

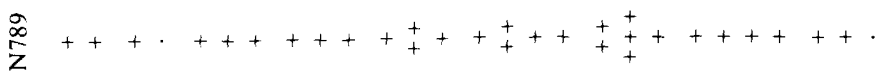

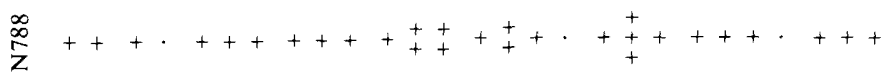

$\underset{\mathbf{D}}{\stackrel{\infty}{z}}+++\cdot+++++\cdot+\stackrel{+}{+}+++++++++++++++$.

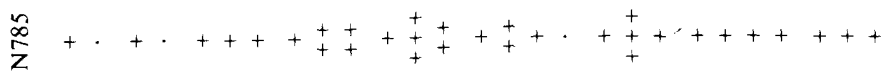

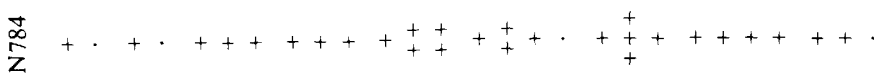

$\underset{\mathbf{z}}{\infty}+++\cdot+++++++++++++++++++++++\cdot$

$\underset{\infty}{\stackrel{2}{z}}+++\cdots++\cdot++\cdot+++++++\cdots++++++++++++$

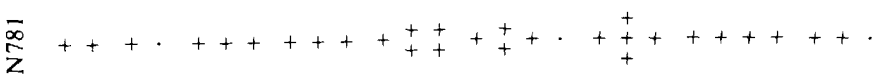

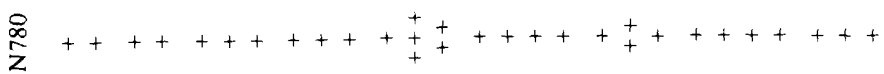

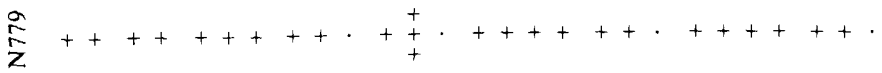

$\underset{z}{\stackrel{\infty}{\gtrless}}+++\cdot+++++\cdot++\frac{+}{+} \cdot+++++++++++++$.

$\underset{\mathrm{Z}}{\mathrm{Z}}+++++++++\cdot+++++++++++++++++++$

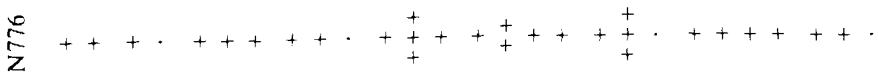

$\underset{\mathrm{z}}{z}+++\cdot+++++\cdot+++++++++++++++++\cdot$

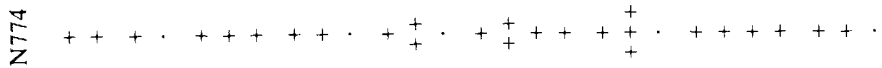

$\underset{\mathrm{E}}{\mathrm{E}}+++\cdot+++++\cdot+\underset{+}{+}++++++++++++++++$.

$\mathrm{b} 0$
0
0

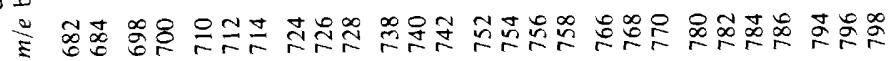

宸 它 
Table 6. Peaks in the mass spectrum of methyl mycolates of Nocardia amarae strain N786 corresponding to anhydromycolates

The main component is denoted by +++ , any component greater than $50 \%$ of the main peak by ++ , and all other significant components by + .

\begin{tabular}{|c|c|c|c|c|c|c|c|}
\hline $\begin{array}{l}\text { No. of carbons } \\
\text { in parent } \\
\text { mycolic acid }\end{array}$ & $m / e$ & $\begin{array}{l}\text { No. of } \\
\text { double } \\
\text { bonds }\end{array}$ & $\begin{array}{l}\text { Relative } \\
\text { intensity }\end{array}$ & $\begin{array}{l}\text { No. of carbons } \\
\text { in parent } \\
\text { mycolic acid }\end{array}$ & $m / e$ & $\begin{array}{l}\text { No. of } \\
\text { double } \\
\text { bonds }\end{array}$ & $\begin{array}{l}\text { Relative } \\
\text { intensity }\end{array}$ \\
\hline $\mathrm{C}_{48}$ & $\begin{array}{l}710 \\
712\end{array}$ & $\begin{array}{l}3 \\
2\end{array}$ & $\begin{array}{l}+ \\
+\end{array}$ & $\mathrm{C}_{56}$ & $\begin{array}{l}822 \\
824\end{array}$ & $\begin{array}{l}3 \\
2\end{array}$ & $\begin{array}{l}++ \\
++\end{array}$ \\
\hline $\mathrm{C}_{50}$ & $\begin{array}{l}738 \\
740 \\
742 \\
744\end{array}$ & $\begin{array}{l}3 \\
2 \\
1 \\
0\end{array}$ & $\begin{array}{c}++ \\
++ \\
+ \\
+\end{array}$ & $\mathrm{C}_{57}$ & $\begin{array}{l}826 \\
836 \\
838 \\
840\end{array}$ & $\begin{array}{l}1 \\
3 \\
2 \\
1\end{array}$ & $\begin{array}{c}++ \\
++ \\
+ \\
+\end{array}$ \\
\hline$C_{52}$ & $\begin{array}{l}766 \\
768 \\
770\end{array}$ & $\begin{array}{l}3 \\
2 \\
1\end{array}$ & $\begin{array}{l}++ \\
++ \\
++\end{array}$ & $\mathrm{C}_{98}$ & $\begin{array}{l}850 \\
852 \\
854\end{array}$ & $\begin{array}{l}3 \\
2 \\
1\end{array}$ & $\begin{array}{c}++ \\
++ \\
+\end{array}$ \\
\hline $\mathrm{C}_{53}$ & $\begin{array}{l}772 \\
780 \\
782\end{array}$ & $\begin{array}{l}0 \\
3 \\
2\end{array}$ & $\begin{array}{l}++ \\
+ \\
+\end{array}$ & $\mathrm{C}_{59}$ & $\begin{array}{l}864 \\
866 \\
868\end{array}$ & $\begin{array}{l}3 \\
2 \\
1\end{array}$ & $\begin{array}{l}+ \\
+ \\
+\end{array}$ \\
\hline & $\begin{array}{l}784 \\
794\end{array}$ & $\begin{array}{l}1 \\
3\end{array}$ & $\begin{array}{c}+ \\
++\end{array}$ & $C_{60}$ & $\begin{array}{l}878 \\
880\end{array}$ & $\begin{array}{l}3 \\
2\end{array}$ & $\begin{array}{l}+ \\
+\end{array}$ \\
\hline$C_{54}$ & $\begin{array}{l}194 \\
796 \\
798\end{array}$ & $\begin{array}{l}3 \\
2 \\
1\end{array}$ & $\begin{array}{c}++ \\
++ \\
+++\end{array}$ & $\mathrm{C}_{61}$ & $\begin{array}{l}880 \\
892 \\
894\end{array}$ & $\begin{array}{l}2 \\
3 \\
2\end{array}$ & $\begin{array}{l}+ \\
+ \\
+\end{array}$ \\
\hline $\mathrm{C}_{55}$ & $\begin{array}{l}808 \\
810 \\
812\end{array}$ & $\begin{array}{l}3 \\
2 \\
1\end{array}$ & $\begin{array}{l}+ \\
+ \\
+\end{array}$ & $C_{62}$ & $\begin{array}{l}896 \\
906 \\
908\end{array}$ & $\begin{array}{l}1 \\
3 \\
2\end{array}$ & $\begin{array}{l}+ \\
+ \\
+\end{array}$ \\
\hline
\end{tabular}

Table 7. Percentage composition of fatty acid methyl esters observed on pyrolysis gas chromatography of methyl mycolates of strains of Nocardia amarae

Equivalent chain length*:

OV-1 (2 m)

Equivalent chain length*:

Silar 10C $(6 \mathrm{~m})$

Assignment $\dagger$

Nocardia amarae N667

N774

N775

N776

N777

N778

N779

N780

N781

N782

N783

N784

N785

N786

N787

N788

N789

N790

N791

\begin{tabular}{llr}
14.0 & 15.5 & 16.0 \\
14.0 & 15.4 & 16.0 \\
$14: 0$ & - & $16: 0$ \\
- & - & 15.7 \\
0.4 & - & 8.8 \\
- & - & 8.9 \\
- & - & 13.7 \\
- & - & 11.5 \\
- & - & 6.6 \\
0.3 & - & 9.1 \\
0.3 & - & 26.2 \\
0.7 & - & 25.2 \\
0.4 & - & 9.0 \\
0.2 & - & 8.1 \\
1.0 & - & 28.5 \\
$\operatorname{tr}$ & - & 22.7 \\
0.5 & - & 46.2 \\
0.4 & 4.4 & 11.5 \\
0.8 & - & 22.7 \\
\hline- & - & 23.3 \\
0.9 & - & 9.8 \\
0.3 & - & 22.7
\end{tabular}

$15 \cdot 6$

$16 \cdot 7$

16:1

31.5

37.2

41.8

$30 \cdot 7$

46.2

36.9

47.3

34.5

18.0

49.0

49.8

19.3

18.0

1.4

46.7

21.9

18.3

50.6

$20 \cdot 3$
$16 \cdot 6$

$18 \cdot 0$

$17 \cdot 6$

$17 \cdot 7$

$18 \cdot 0$

$18 \cdot 7$

17: 1

18:0

$10 \cdot 1$

$2 \cdot 2$

1.0

tr

1.8

$2 \cdot 2$

$4 \cdot 3$

$1 \cdot 8$

$0.9 \quad 2.2$

1.6

$2 \cdot 8$

$8 \cdot 5$

$4 \cdot 1$

$2 \cdot 3$

$3 \cdot 0$

3.4

$4 \cdot 1$

37.4

$3 \cdot 3$

$3 \cdot 7$

4.0

$2 \cdot 0$

$2 \cdot 7$
$18: 1$

$41 \cdot 8$

50.3

$47 \cdot 1$

$49 \cdot 5$

$40 \cdot 5$

53.4

39.0

28.9

49.4

38.0

35.4

$44 \cdot 2$

48.8

$11 \cdot 9$

$31 \cdot 2$

$49 \cdot 5$

$54 \cdot 5$

$33 \cdot 5$

$51 \cdot 8$

tr, Trace.

* According to Miwa et al. (1960).

$\ddagger 14: 0,16: 0$ and 18:0 denote methyl esters of tetradecanoic, hexadecanoic and octadecanoic acids; $16: 1$, 17:1 and 18:1 denote methyl esters of hexadecenoic, heptadecenoic and octadecenoic acids. 
Table 8. Peaks corresponding to molecular ions in the mass spectra of menaquinones isolated from strains of Nocardia amarae

The main component of each series is denoted +++ , any components greater than $50 \%$ of the main peak by ++ , and all other significant components by + .

\begin{tabular}{|c|c|c|c|c|c|}
\hline \multirow{2}{*}{$\begin{array}{c}\text { Menaquinone isoprenologue } \\
\text { Degree of hydrogenation } \\
m / e\end{array}$} & \multirow{2}{*}{$\begin{array}{c}\mathrm{MK}-7 \\
\mathrm{H}_{2} \\
650\end{array}$} & \multicolumn{2}{|c|}{ MK-8 } & \multicolumn{2}{|c|}{ MK-9 } \\
\hline & & $\overline{716}$ & $\begin{array}{c}\mathrm{H}_{2} \\
718\end{array}$ & $\overline{784}$ & $\begin{array}{c}\mathrm{H}_{2} \\
786\end{array}$ \\
\hline Nocardia amarae N667 & + & + & ++ & + & +++ \\
\hline N774 & + & - & + & + & +++ \\
\hline N775 & + & - & + & + & +++ \\
\hline N776 & + & + & ++ & + & +++ \\
\hline N777 & + & + & ++ & + & +++ \\
\hline N778 & + & + & ++ & + & +++ \\
\hline N779 & + & + & + & + & +++ \\
\hline N780 & + & + & + & + & $t+t$ \\
\hline N781 & + & + & + & + & +++ \\
\hline N782 & + & - & + & ++ & +++ \\
\hline N783 & + & - & + & + & +++ \\
\hline N784 & + & - & + & + & +++ \\
\hline N785 & + & - & + & + & +++ \\
\hline N786 & + & + & + & + & +++ \\
\hline N787 & + & + & ++ & + & +++ \\
\hline N788 & + & - & + & + & +++ \\
\hline N789 & + & - & + & + & +++ \\
\hline N790 & + & - & + & + & +++ \\
\hline N791 & + & - & + & + & +++ \\
\hline
\end{tabular}

distinguished from other nocardiae, which possess $\mathrm{MK}-8\left(\mathrm{H}_{4}\right)$ as the major isoprenologue, but not from mycobacteria or all rhodococci (Collins et al., 1977; Yamada et al., 1976, 1977). Mycobacteria can easily be distinguished from nocardiae, including $N$. amarae, as their mycolates are insoluble in ethanol/diethyl ether (Hecht \& Causey, 1976) and much more complex in structure (Minnikin \& Goodfellow, 1980).

Nocardia amarae is clearly a good species which is related to established species of Nocardia on the basis of chemical, genetical and numerical phenetic data. Its assignment to Nocardia sensu stricto is not, however, unambiguous, as $N$. amarae strains only contain dihydrogenated menaquinones with nine isoprene units, possess mycolic acids which release $\mathrm{C}_{16}$ and $\mathrm{C}_{18}$ monounsaturated fatty acids on pyrolysis, are unable to grow in lysozyme broth (Lechevalier \& Lechevalier, 1974), while the type strain is not lysed by nocardiophages (Williams et al., 1980). Further work using powerful methods such as in vitro nucleic acid pairing techniques is required to determine whether or not $N$. amarae is a genus in its own right.

The authors are indebted to Dr M. P. Lechevalier who kindly provided the $N$. amarae strains, to Dr L. Alshamaony for help with the initial lipid studies, to Karen Fleming and A. Temple for technical assistance and to the Medical Research Council (grant G974/522/S) for supporting this work. Mass spectra were recorded by P. Kelly and S. H. Addison.

\section{REFERENCES}

Collins, M. D., Pirouz, T., Goodfellow, M. \& Minnikin, D. E. (1977). Distribution of menaquinones in actinomycetes and corynebacteria. Journal of General Microbiology 100, 221-230.
Collins, M. D., Goodfellow, M. \& Minnikin, D. E. (1982). A survey of the structures of mycolic acids in Corynebacterium and related taxa. Journal of General Microbiology 128, 129-149. 
EtÉmADI, A.-H. (1967). The use of pyrolysis gas chromatography and mass spectroscopy in the study of the structure of mycolic acids. Journal of Gas Chromatography 5, 447-456.

Goodfellow, M. (1971). Numerical taxonomy of some nocardioform bacteria. Journal of General Microbiology 69, 33-80.

Goodfellow, M. \& Alderson, G. (1977). The actinomycete-genus Rhodococcus: a home for the 'rhodochrous' complex. Journal of General Microbiology 100, 99-122.

Goodfellow, M. \& MinNikin, D. E. (1977). Nocardioform bacteria. Annual Review of Microbiology 31, 159-180.

GoodfEllow, M. \& MinNikin, D. E. (1981). The genera Nocardia and Rhodococcus. In The Prokaryotes: $A$ Handbook of Habitats, Isolation, and Identification of Bacteria, pp. 2016-2027. Edited by M. P. Starr, H. Stolp, H. G. Trüper, A. Balows \& H. G. Schlegel. Berlin: Springer Verlag.

Goodfellow, M. \& Pirouz, T. (1982). Numerical classification of sporoactinomycetes containing meso-diaminopimelic acid in the cell wall. Journal of General Microbiology 128, 503-527.

Goodfellow, M., Orlean, P. A. B., Collins, M. D., Alshamaony, L. \& Minnikin, D. E. (1978). Chemical and numerical taxonomy of strains received as Gordona aurantiaca. Journal of General Microbiology 109, 57-68.

Goodfellow, M., Weaver, C. R. \& Minnikin, D. E. (1982). Numerical classification of some rhodococci, corynebacteria and related organisms. Journal of General Microbiology 128, 731-745.

Gordon, R. E. \& MiHM, J. M. (1962). Identification of Nocardia caviae (Erikson) nov.comb. Annals of the New York Academy of Sciences 98, 628636.

Gordon, R. E., Mishra, S. K. \& Barnett, D. A. (1978). Some bits and pieces of the genus Nocardia: $N$. carnea, $N$. vaccinii, $N$. transvalensis, $N$. orientalis and $N$. aerocolonigenes. Journal of General Microbiology 109, 69-78.

HeChT, S. T. \& CAUSEY, W. A. (1976). Rapid method for the detection and identification of mycolic acids in aerobic actinomycetes and related bacteria. Journal of Clinical Microbiology 4, 284-287.

LACEY, J. \& GoODFEllow, M. (1975). A novel actinomycete from sugar-cane bagasse: Saccharopolyspora hirsuta gen. et sp.nov. Journal of General Microbiology 88, 75-85.

LecheVAliER, H. A., LecheValier, M. P., Wyszkowski, P. A. \& MARIAT, F. (1976). Actinomycetes found in sewage-treatment plants of the activated sludge type. In Actinomycetes: The Boundary Micro-organisms, pp. 227-247. Edited by T. Arai. Tokyo: Toppan Co.

Lechevalier, M. P. \& Lechevalier, H. (1970). Chemical composition as a criterion in the classification of aerobic actinomycetes. International Journal of Systematic Bacteriology 20, 435-444.

Lechevalier, M. P. \& Lechevalier, H. A. (1974). Nocardia amarae sp.nov., an actinomycete common in foaming activated sludge. International Journal of Systematic Bacteriology 24, 278-288.

LecheVAlier, M. P., De Bièvre, C. \& Lechevalier, H. (1977). Chemotaxonomy of aerobic actino- mycetes: phospholipid composition. Biochemical Systematics and Ecology 5, 249-260.

Minnikin, D. E. \& GoodfELlow, M. (1980). Lipid composition in the classification and identification of acid-fast bacteria. In Microbiological Classification and Identification, pp. 189-256. Edited by $M$. Goodfellow \& R. G. Board. London: Academic Press.

Minnikin, D. E. \& Goodfellow, M. (1981). Lipids in the classification of actinomycetes. Zentralblatt für Bakteriologie, Parasitenkunde, Infektionskrankheiten und Hygiene (Abteilung I), Supplement 11, 99-109.

Minnikin, D. E., Alshamaony, L. \& Goodfellow, M. (1975). Differentiation of Mycobacterium, Nocardia and related taxa by thin-layer chromatographic analysis of whole-organism methanolysates. Journal of General Microbiology 88, 200-204.

Minnikin, D. E., Goodfellow, M. \& Collins, M. D. (1978). Lipid composition in the classification and identification of coryneform and related taxa. In Coryneform Bacteria, pp. 85-160. Edited by I. J. Bousefield \& A. G. Callely. London: Academic Press.

Minnikin, D. E., Hutchinson, I. G., Caldicott, A. B. \& Goodfellow, M. (1980). Thin-layer chromatography of methanolysates of mycolic acid-containing bacteria. Journal of Chromatography 188, 221-233.

Miwa, T. K., MikolajczaK, K. L., Earle, F. R. \& WOLFF, I. A. (1960). Gas chromatographic characterization of fatty acids. Analytical Chemistry 32, 1739-1742.

Mordarska, H., Mordarski, M. \& Goodfellow, M. (1972). Chemotaxonomic characters and classification of some nocardioform bacteria. Journal of General Microbiology 71, 77-86.

Mordarski, M., Szyba, K., TKaCz, A. \& Kaszen, I. (1977). Comparison of DNA homology in Nocardia amarae, $N$. autotrophica and Rhodococcus strains. The Biology of the Actinomycetes and Related Organisms 12, 21-26.

Mordarski, M., Goodfellow, M., Szyba, K., Tkacz, A., Pulverer, G. \& SchaAl, K. P. (1980). Ribosomal ribonucleic acid similarities in the classification of Rhodococcus and allied taxa. Journal of General Microbiology 118, 313-319.

ORCHARD, V. A. \& GOODFELlOW, M. (1980). Numerical classification of some named strains of Nocardia asteroides and related isolates from soil. Journal of General Microbiology 118, 295-312.

Orchard, V. A., Goodfellow, M. \& Williams, S. T. (1977). Selective isolation and occurrence of nocardiae in soil. Soil Biology and Biochemistry $\mathbf{9}$, 233-238.

SNEATH, P. H. A. (1957). The applications of computers to taxonomy. Journal of General Microbiology 17, 201-226.

SNeATH, P. H. A. (1968). Vigour and pattern in taxonomy. Journal of General Microbiology 54, $1-11$.

SNeath, P. H. A. \& Sokal, R. R. (1973). Numerical Taxonomy. The Principles and Practice of Numerical Classification. San Francisco: W. H. Freeman.

SokAL, R. R. \& Michener, C. D. (1958). A statistical 
method for evaluating systematic relationships. Kansas University Science Bulletin 38, 1409-1438.

Tsukamura, M. (1974). A further numerical taxonomic study of the rhodochrous group. Japanese Journal of Microbiology 18, 37-44.

Williams, S. T., Wellington, E. M. H. \& Tipler, L. S. (1980). The taxonomic implications of the reactions of representative Nocardia strains to actinophage. Journal of General Microbiology 119 , 173-178.

WisharT, D. (1968). A Fortran II Program for
Numerical Taxonomy. St Andrews: University of St Andrews.

Yamada, Y., Inouye, G., Tahara, Y. \& Kondo, K. (1976). The menaquinone system in the classification of coryneform and nocardioform bacteria and related organisms. Journal of General and Applied Microbiology 22, 203-214.

Yamada, Y., Ishikawa, T., TAHARA, Y.\& Kondo, K. (1977). The menaquinone system in the classification of the genus Nocardia. Journal of General and Applied Microbiology 23, 207-216. 